W stużbie tradycji i odnowy liturgicznej. 50 lat Instytutu Liturgicznego w Krakowie (1968-2018), red. P. Nowakowski, J. Mieczkowski, Kraków 2019, s. 333-346.

ISBN 978-83-7438-849-8 (wersja drukowana), ISBN 978-83-7438-850-4 (wersja online) DOI:http://dx.doi.org/10.15633/9788374388504.25

Vasyl Rudeyko

\title{
Liturgical Theology in the Ukrainian Greek Catholic Church: An Attempt at Restoration
}

The liturgy of the Church, its prayer, is always an attempt to defragment time, to introduce eternity into the time. Gathered for prayer, the Church not only mentions the past, the time when the Lord actively acted in the lives of specific people, nations and the Church itself; it tries to actualize these events for those, who are gathered here and now for a living experience of the presence of Jesus Christ, who assured this presence, where faithful are gathered in His name. From this point of view, each liturgical meeting is an attempt to return to the sources, or rather to the Source, which, according to the words of the Gospel, flows up in the hearts of those who have accepted the Word of God.

The prayer of the Church, which consists of a great variety of experiences of meeting with God and carries in itself the confession of His greatness, goodness and love, must, first of all, be subjected to a critical review in the context of returning to its origins - if we want properly to perceive it, interpret it and make it our own experience here and now.

For the Ukrainian Greek Catholic Church (UGCC), which began its institutional existence from the moment of the union in Brest in 1596, it was 
very important to preserve its liturgical tradition, and unity with its origins. ${ }^{1}$ Since this church geographically, but also culturally and politically, was on the edge of two worlds - the East and the West - in its ideas of reform and their analysis, it is necessary not to underestimate the issues involved in their own identity itself. In order to better understand the underlying foundations of the liturgical movements that arose in the Church, we must briefly outline several historical aspects.

\section{The Beginnings}

The search for its own cultural roots encouraged UGCC to look for the sources of its tradition, which, in turn, led to the establishment of Greek-Slavic schools. ${ }^{2}$ As a pastor in Brest, Ipatij Potiy, one of the supporters and promoters of the union with Rome, founded a school for the study of theology. ${ }^{3}$ In 1628, similar schools were founded in Novgorodok and in other cities, ${ }^{4}$ and their function indicates some attempts to distance the Ukrainian Church from the prevailing Latin theology and terminology of the time. ${ }^{5}$

It should be emphasized here that at that period the study of theology by priests in general was reduced to the ability to read liturgical books, and therefore, it can be said, was in its essence liturgical. ${ }^{6}$ In addition, it must be taken into account that the diversity of theologically polemical issues at that time can for the most part be reduced to discussions about ritual affairs.

In this period, it is very difficult to speak of a certain liturgical theology, yet it is important to examin a work, which in some ways outlines a vision

1 С. П. Галадза, Аітургічне питання і розвиток богослужінь напередодні Берестейської унї аж до кіния XVII стохіття. Берестейська унія та внутрішне життя Церкви в XVII столітті, Аьвів 1997, р. 2.

2 С. Б. Гудзяк, Історія відокремлення: Киӥвська митрополія, Царгородський партіархат і генеза Берестейської унії, “Ковчег” 1 (1993), р. $11 \mathrm{ff}$.

3 Сf. С. Сеник, Аатинізація в Украӥнській католицькій Церкві, Аьвів 199о, р. 24.

4 S. Senyk, The Education of the Secular Clergy in the Ruthenian Church before the Nineteenth Century, "Orientalia Christiana Periodica" 53 (1987), p. $401 \mathrm{ff}$.

5 S. Senyk, The Education..., p. $395 \mathrm{ff}$.

6 S. Senyk, The Education..., p. $387 \mathrm{ff}$. 
of liturgical theology for those times. It is the book of the Basilian monk Lev Kyshka Various Questions on Sacraments (1697),7 which, after Zamoisky Synod (1720), became almost the official textbook for the Uniate priests, despite the disapproval of the Roman authorities. Sophia Senyk notes that certain practices proposed by this textbook contradicted the established norms of the Latin Church and the author needed to defend his theological position, which he did in a rather sharp tone. ${ }^{8}$

The resolutions of the already mentioned Zamoisky Synod ${ }^{9}$ had caused dissatisfaction not only among the Orthodox, for whom the Latinizing intervention in the liturgical texts was a sign of the creation of a "hybrid" rite, but also among the Catholic Ruthenians, for whom these reforms did not correspond to the spirit of Eastern tradition. Such a confrontation within the Uniate Church created a liturgical movement in the middle of the $19^{\text {th }}$ century. The Seminary for the Greek Catholics, the so-called Barbareum, founded in 1774 in Vienna played an important role in this liturgical movement. The study of theology, without much Latin influence, contributed to the development among the graduates of this institution and their successors in the "pure rite" liturgical movement, its main idea which was the aim of a return to a pure Byzantine rite.

The pure Byzantine rite, as the supporters of this movement saw it, was the modern (synodal) rite of the Russian Orthodox Church. It would be very interesting to investigate the possible impact on this process from the Moscow (1678) and Kyiv (1701) Theological Academies, whose main accent in the so-called "Synodal period" was an in-depth source study of the liturgical heritage itself.

7 Cf. S. Senyk, The Education..., p. $410 \mathrm{off}$.

8 Cf. S. Senyk, The Education..., p. 411.

9 About this synod: Ю. Федорів, Замойський Синод 1720 р., "Bohoslovia" 43 (1972); I. Онищук, Замойський Синод 1720 р.: історично-юридичний аналіз рішень та постанов, Івано-Франківськ 2007; М. Крокош, Замойський Синод - оновлення чи тупик?, “Патріархат" 5 (2009), р. 26f; С. Мудрий, Провінційний Синод у Замості 1720 р. Б. Постанови, Пер. I. Козовик, Вид. І. Пелехатий, Івано-Франківськ 2006, р. 132-299; перше латинське видання див, Synodus provincialis ruthenorum habita in civitate Zamosciae anno MDCCXX, Romae 1724; на руській мові, Додаток до чинностей і рішень Руского Провинціяльного Собора в Галичині отбувшого ся во Аьвові в р. 1891, Аьвів 1897. 


\section{2. "Liturgical movement" in the UGCC in the $19^{\text {th }}$ Century ${ }^{10}$}

The new status of the UGCC in the Habsburg Empire encouraged the study of its own liturgical tradition. In 1862 the Austrian authorities in Galicia noticed a certain "liturgical movement."11 The theoretical interest in their own liturgical heritage often expanded into some practical implementation in pastoral life: the restoration of the iconostases, the removal of the side altars, the introduction of a musical liturgical heritage as a counterbalance to the so-called "Polish" pieties, long beards, and the Greek klobucks began to appear again in the Greek-catholic churches in Galicia. In addition to practical liturgical implementations, one can also observe great theoretical interest in liturgical issues.

In particular, in a number of church magazines, such as "Russky Sion", "Halytskyj Sion”, "Bohoslovskyj almanakh", "Dushpastyr", "Prapor", "Bohoslovskyj visnyk", "Katholytskyj vskhid", "Nyva”, “Tserkovnyj vostok”, "Bohoslovija", "Zapysky OSBM", from the 1850 os to the beginning of the Second World War, there were published more than 300 separate and serial articles, and reviews on liturgical topics that covered both the history of the liturgy and its theological and pastoral dimensions. This is more than the articles published on church history during this period. Among the main contributors to liturgical articles, we can note Dr. Josyf Milnitsky, Ignatij Halka, Izydor Dolnytsky, Aleksij Toronsky ${ }^{12}$, and later Titus Myshkovsky, Havryjil Kostelnik and others.

It should be especially noted that the study of these authors and their works is still in need of detailed research, since during the years of the communist regime their works, if not destroyed, became bibliographic rarities. ${ }^{13}$ It is a very interesting fact that many of these authors in their investigations were not limited to research and presentation of their own

10 More about this: J.-P. Himka, Religion and Nationality in Western Ukraine. The Greek Catholic Church and the Ruthenian National Movement in Galicia, 1867-1900, Montreal-Ithaca 1999.

11 Cf. P. Galadza, The Theology and Liturgical Work of Andrei Sheptytsky (1865-1944), Rome 2004, p. 248.

12 А. Торонський, Литургіка, Львів 1894 (2-е видання).

13 Поученіє о обрядах христіанских первіє в книзі НАРОДОВІЩАНІЯ, или СЛОВО к НАРОДУ Католіческому зовомой, по Благословенію єще єго Преосвященства С. П. Кир Сильвестра 
traditions. From their publications one can see that like their Western and Russian colleagues, they made an attempt to learn from the ancient liturgical treasury of other rites ${ }^{14}$ or to study some of their own forgotten liturgical traditions such as Liturgy of St. James. ${ }^{15}$

The liturgical work of the theologians, on one hand, the practical consequences of the liturgical movement in Galicia and the reaction of official church and secular authorities, on the other hand, caused the convocation of a church synod in Lviv in $1891^{16}$ and series of the synods in the years of $1927-1933 .{ }^{17}$

In 1929, an inter-diocesan liturgical commission was convened to review the liturgical books of the UGCC. Its members included specialists in liturgy, who were available to Metropolitan Andrey Sheptytskyy at that time: Ivan Buchko, Theodosij Halushchynskyy, Platon Martynyak, Tyt Myshkovskyy, Domet Sadovskyy, Ivan Lutsyk, Havryjil Kostelnyk, Clement Sheptytskyy and Stepan Reshetylo. Each of these specialists had to do some scholarly work on one of the liturgical books, submit a lecture and suggest corrections. ${ }^{18}$ In most cases, they concerned themselves with

Лубінієцъкаго Рудницкаго, Почаїв 1779; А. Духнович, Аитургический катехизис, Аьвів 1855; М. Попель, Литургіка, Львів 1863; Є. Фенцик, Аитургіка, Будапешт 1878.

14 Іос. Мільницкій, О старих греческих і восточних Літургіях, росправа історично-літургічна, "Рускій Сіон" 1 (1871) ч. 1. - p. 13-14; 2. - p. 55-56; 3. - p. 97-100; 4. - p. 131-133; 5. - p. 170-172; 6. - p. 198-200; 7. - p. 233-236; 10. - p. 332-334; 13. - p. 427-430; 14. - p. 461-463; 15. - p. 496-500; 17. - p. 557-559; 18. - p. 588-590; 20. - p. 652-657; 21. - p. 683-687; 22. p. 715-719; 2 (1872) 1. - p. 23-25; 2. - p. 49-53; 3. - p. 8o-83; 5. - p. 157-159; 6. - p. 191-192; 8. - p. 239-242; 9. - p. 277-280; 10. - p. 309-312; 12. - p. 366-371; 14. - p. 441-445; 16. - p. 499503; 17. - p. 520-525; 18. - p. 553-56o; 19. - p. 598-605; 20. - p. 633-637; 21. - p. 654-658; 22. p. 689-694; 23. - p. 721-726; 24. - p. 751-754; 3 (1873) 1. - p. 10-19.

15 Аітургія св. Ап. Якова, “Нива” 33 (1938) ч. 3, р. 119.

16 More about this synod: J.-P. Himka, Religion and Nationality ..., p. 101-121; Видання nостанов синоду див. Чинности і Рішеня руского провинціяльного Собора в Галичині отбувшого ся во Аьвові в році 1891, Аьвов 1896; Доповнення до діянь синоду див, Додаток до чинностей $i$ рішень Руского Провинціяльнного Собора в Галичині отбувщого ся во Аьвові в р. 1891, Аьво 1897.

17 Cf. P. Galadza, The Theology and Liturgical Work of Andrei Sheptytsky..., p. 316-349.

18 Г. Аончина, Требник Митрополита Андрея Шептицъького (Дьвів, 1925-1926): Спроба літургійної віднови, Рим 2001, р. 60. 
the so-called "Hybridisms," that is, with the customs of the Roman Catholic tradition, which formally or unofficially had entered the liturgical tradition of the UGCC after the Union of Brest. Yet in their renewal proposals, ${ }^{19}$ one can see a tangible desire for much broader changes. From the published abstracts of these proposals, it can be concluded that the liturgical movement of the Russian Orthodox Church, initiated by the investigations of the professors of the Moscow Theological Academy, Alexander Gorsky (1812-1875) and Capiton Nevostruyev, were not unnoticed by the scholars of the UGCC. ${ }^{20}$

\section{Liturgical Issues in the Post-War Period}

Although the destruction of the UGCC by the Soviet regime 1946 and the years of the UGCC in the underground prevented further work in the liturgical field in Ukraine, the systematic study and renewal of the liturgy were continued by bishops of the Ukrainian diaspora, primarily in Western Europe and North America. In the context of preparation for the Second Vatican Council and participation in it, the bishops of the UGCC intensively discussed the issues of liturgical language, the adaptation of liturgical services of the Byzantine tradition to the Gregorian calendar, the length of worship, the practices of the past, as well as the return to the authentic "old" traditions of the UGCC. As in the days of Metropolitan Sheptytskyy, most of these issues, however, were debated in the area of purification of worship from Latin influence. ${ }^{21}$ One of the greatest achievements of the renewal of the liturgical piety of the UGCC at that time was the attempt to translatie the liturgical books into Ukrainian. Due to the activity of the liturgical commission established by Patriarch Josyf after his return from exile, a number of liturgical texts, in particular the liturgical Gospel, the Apostle, three liturgies, and a small trebnyk, were translated into Ukrainian.

19 Д. Блажейовський, Рим і обрядво-літургічні дискусії у патріаршій київській вселенській церкві між двома світовими війнами, Аьвів 2002, р. 192-198.

20 Cf. Е. Ковч, Чому наші від нас утікають?, Аьвів 1932.

21 More information on the subject: T. M. Németh, Eine Kirche nach der Wende. Die Ukrainische Griechisch-Katholische Kirche im Spiegel ihrer synodalen Tätigkeit, Freistadt 2005, p. 31-39. 
Simultaneously with the patriarchal commission, another translation group from the monks of the Order of St. Basil the Great completed the translation of a kind of anthologion - a collection for services of the daily hours. The two groups were significantly different in their approach to translation. The more conservative "patriarchal" translation that used many archaisms and was more faithful to the Church Slavonic liturgical books, was in opposition to the translation of the "Vasilianka" - an attempt to translate the text into a more modern spoken language, with headings and texts which adapted the format of the Byzantine offices to their equivalent in the Latin breviary. ${ }^{22}$

The main catalyst for the situation of liturgical theology came with the foundation of the Ukrainian Catholic University of St. Clement in Rome by Patriarch Joseph Slipyj after his return from the Soviet exile. It was there that the modern liturgists, such as Glib Lonchyna, ${ }^{23}$ Prof. Rafayil Turkonyak, ${ }^{24}$ Prof. Mykhayil Petrowycz, ${ }^{25}$ Prof. Petro Galadza, ${ }^{26}$ Prof. Mark Morozovych, ${ }^{27}$ were encouraged to attend liturgical studies.

Among the works of alumni of this university should be distinguished works on the liturgical sources done by prof. O. Horbach, ${ }^{28} \mathrm{M}$. Marusyn ${ }^{29}$

22 See T. M. Németh, Eine Kirche nach der Wende, p. 49-51.

23 Г. Лончина, Требник Митрополита Андрея Шептицьвкого (Львів, 1925-1926): Спроба літургійної віднови, Аьвів 2014.

24 Р. Турконяк, Аітургія Передшеосвячених дарів в Украӥнській Церкві, Львів 2002.

25 M. Petrowycz, Bringing Back the Saints: The Contribution of the Roman Edition of the Ruthenian Liturgical Books (Recensio Ruthena, 1940-1952) to the Commemoration of Slavic Saints in the Ukrainian Catholic Church [A dissertation submitted to the Faculty of Theology, Saint Paul University, in partial fulfillment of the requirements for the degree of Doctor of Philosophy in Theology (and Doctor of Theology)], Ottawa 2014.

26 P. Galadza, The Theology and Liturgical Work of Andrei Sheptytsky...

27 M. Morozowich, Holy Thursday in the Jerusalem and Constantinopolitan Traditions. The Liturgical Celebrations from the Fourth to the Fourteenth Centuries [PhD diss., Pontificio Istituto Orientale (Rome), 2002].

28 О. Горбач, Три Церковнослов'янські Літургічні рукописні Тексти Ватиканської Бібліотеки. (Tres Textus Liturgici Linguae Ecclesiasticae (Paleo) - Slavieae in Manuscriptis Vaticanis), Рим 1966.

29 М. Марусин, Чини Святительських Служб в Київському Евхологіоні з початку XVI cm. (Ordinum Pontificalium in Euchologio Kioviensi saec. XVI expositio), Рим 1966. 
and others. In any case, the influence of this institution on the preservation and development of the liturgical science of the UGCC can not be overestimated.

In parallel with the university, liturgical studies were also carried out at the schools of Basilian fathers. From this environment, we must mention the works of Bishops Meletius Soloviy ${ }^{30}$ and Lawrence Hutsulyak, ${ }^{31}$ Fr. Julian Katrij, ${ }^{32}$ et al.

If we look at the specifics of the liturgical studies mentioned above, we will see that most of them follow the historical liturgy and liturgical sources, which actually is quite understandable taking into consideration the state of research of liturgical sources at that time.

\section{The Issue of Liturgical Piety in the UGCC after Leaving the Underground}

The exit of the UGCC from the underground in 1990 also affected the issues of liturgical piety. As Oleksandr Petrynko noted in his study: "desire of the liturgical renewal is again and again evident, but in practice it became an insoluble problem." 33 In the synodal decrees one can see, on one hand, the sincere desire to follow the Byzantine tradition of "the churches of Volodymyr's baptism," on the other hand, the emphasis on preserving the "Latinisms" of the decrees of the synod in Zamost. ${ }^{34}$

One can consider in different ways what might seem at first glance such inconsistency of views on the liturgical piety of the episcopate of the

\footnotetext{
30 М. Соловій, Божественна Аітургія: історія - розвиток - пояснення, Рим 1964.

31 А. Гуцуляк, Божественна Літургія Йоана Золотоустого в Київській Митропохї̈ після унї з Римом (період 1596-1839 рр.), Аьвів 2004.
}

32 Ю. Катрій, Пізнай свій обряд, Аьвів 2004.

33 O. Petrynko, Aufdem Weg zu einer Liturgiereform in der Ukrainischen Griechisch-katholischen Kirche, "Liturgisches Jahrbuch" 6о (2010) Heft 2, p. 103. Див. також O. Petrynko, Die Liturgiekonstitution des zweiten Vaticanums und die aktuelle Gestalt der Göttlichen Liturgie in der Ukrainischen Griechischß3katholischen Kirche (UGKK), “Ostkirchliche Studien” 6o (2011) Heft 1, p. $141-143$.

34 T. M. Németh, Eine Kirche nach der Wende, p. 214-216. 
UGCC. Yet, this situation, although it looks strange, is understandable in the historical circumstances of the UGCC of those times. The confrontation between the "Orientals" and "Latins," which was not solved during the liturgical activity of Metropolitan Andrey Sheptytsky, continued during the underground because of the impossibility of scientific research that could answer those disputed questions. The UGCC today is aware of this problem as can be seen from the letter on liturgical issues from 2007:

The lack of awareness [of the historical development of the content and forms of our rite - V. R.] is caused by the difficult historical circumstances in which our Church lived for centuries. There was lack of a good number of true specialists of our own liturgical tradition, and, therefore, authoritative books, liturgical catechisms and studies, from which clergy, monasticism and lay people could receive reliable information about our church rite. Therefore, the amateur initiatives of individual clerics or monastic communities freely penetrated the sacrament. Without proper knowledge, supporters or opponents of such a novelty relied on purely emotional arguments - "like or dislike," and because of the lack of a sense of ecclesiastical discipline, those newcomers gained the right to exist. To give their own preferences a greater weight, such "reformers" speculatively dressed them in denominational "garments" and then called their innovations "truly Catholic" or "true Orthodox," "modernist" or "schismatic." 35

\section{Lviv Theological Academy, Institute of Liturgical Sciences, Department of Liturgical Sciences of UCU}

It is clear that after more than 70 years of the Soviet period the renewal of liturgical theology is not such an easy matter. Until 2006, Ukrainian education did not regard theology as a scientific discipline at all, but in spite of this, in 1994 the Lviv Theological Academy (in 2002 it was reorganized into the Ukrainian Catholic University), renewed its existence. First attempts at the restoration of the liturgical science were not supported by the state: the

35 Послання Синоду Єпископів Києво-Галицького Верховного Архиєпископства про літургійні питання // https:/risu.org.ua/ua/index/resourses/church_doc/ugcc_doc/33932/ (10.02.2018). 
LTA did not even dream of state recognition. The LTA simply lacked the staff (faculty). On the other hand, the institution got new experience when it welcomed such professors from abroad as Robert Taft, Peter Galadza, Andrew Quinlan, Mykhaylo Petrovych and others. Although the students did not always properly understand their English, professors brought the latest methods of liturgical theology at that time and encouraged students to study abroad at the leading centers of liturgical science, for example at the Oriental Institute in Rome.

The LTA had the usual liturgical program, which consisted of five "classical" subjects. Also the Institute of Liturgical Sciences was created in the LTA, ${ }^{36}$ its first director was Prof. Petro Galadza and his deputy was Prof. Yuriy Yasinovskyy. From its beginning the focus of this institution was on studying the sources of church singing, and the main project - the creation of a base of Ukrainian irmologions. The Institute succeeded in numerous source and theoretical publications, as well as in conducting annual international scientific conferences that attracted church music scholars from around the world. Since 2016 the Institute has been renamed as the Institute of Liturgical Singing in accordance with the specifics of its main activities.

After the inauguration of the Ukrainian Catholic University and success in recognizing theology by the educational community of Ukraine, the issue of establishing a department of liturgical sciences became one of the top priorities. The sufficient number of specialists who had completed their doctoral studies at foreign universities allowed the creation in 2010 of the Department of Liturgical Sciences of UCU,37 led by Prof. Mykhailo Petrovych. In the inaugural speech at the opening of the department, he emphasized:

The rapid history of liturgical development and disputes about it in the last four centuries showed how central the liturgical practice for the Church was, but unfortunately many liturgical reforms and discussions were based on confessional and political preferences or prejudices instead of genuine knowledge of their native Kyiv liturgical tradition and its theological and spiritual content. Liturgical life is a mighty river fed by the spiritual power of God's people, but it happens that it can itself be the cause and object of disputes,

36 See webpage: http://icm.ucu.edu.ua/ (10.02.2018).

37 See webpage: http://theological.ucu.edu.ua/kafedry/kafedra-liturgiky/ (10.02.2018). 
appeals, distrust and hostility, when theological and spiritual priorities are inferior to other priorities. [...] liturgical subjects should play a much more active role in the spiritual and academic integration, harmonization of all the subjects of the theological program, and also - and this is not the least - to help teachers and students of the FBF make maximum use of the "ontological spiritual foundation of theology," which is liturgical experience; to help each one open for himself and generously share the source of theology, which is the liturgical life of the Church. If for every theologian this is necessary, the more vital it is for seminarians for whom liturgical life is the core of their pastoral ministry for their communities. ${ }^{38}$

It is clear from this speech that the study of liturgy at the UGCC remains faithful to tradition. Its main interest is, first of all, applied liturgy, that is, not only the theoretical presentation of certain theological phenomena associated with the prayer of the church, but also a living connection with the prayer tradition of a particular church, an attempt to comprehend it, point out the sources and problems with the purpose of helping this particular church to use its liturgical tradition in its life. The priorities of the department are the establishment of a school of liturgical sciences through postgraduate and doctoral programs, the creation of a global bibliographic base "Liturgy of the Church of Kyiv," and close cooperation with the Patriarchal Liturgical Commission of the UGCC.

The creation of the department coincided with the founding of the annual international symposia "ad fontes liturgicos," the purpose of which is to exchange experience and methodology for the study of liturgical sources ${ }^{39}$ in which the department from the beginning has actively participated. The emphasis on the study of the sources of liturgical piety in turn encouraged the creation of a series of publications Liturgical Sources at the Department of Liturgical Sciences..$^{40}$

38 М. Петрович, Інавгураціійне слово з нагоди створення кафедри літургійних наук, https://ucu.edu.ua/news/m-petrovych-inavhuratsijne-slovo-z-nahody-stvorennya-kafedry-liturhijnyh-nauk/ (14.02.2018).

39 See the webpage: https://adfontesliturgicos.blogspot.com/ (14.02.2018).

40 Recent publications: В. Рудейко, Часослов за каноном лаври святого отия нашого Сави: Вировадження. Переклад. Коментарі, Аьвів 2016; В. Рудейко, Часослов двадияти чотирьох часів: Вировадження. Переклад, Аьвів 2017. 


\section{The Activities of the Synod of Bishops of the UGCC as a Catalyst for Liturgical Science}

Problems of the revival of liturgical piety can not be solved only by institutionalized instruction, therefore the involvement of a wider audience of specialists in this matter is absolutely crucial for successful liturgical renewal. Already at the synod of 2005 the patriarchal liturgical commission was instructed to organize a scientific and practical conference for "discussing current issues and suggestions on possible areas of activity of the Patriarchal and diocesan liturgical commissions according to real church needs," ${ }^{41}$ in which liturgists-scientists should take part. This indicates the openness of the Church's leadership of the UGCC to scientific research in the area of liturgical piety and the use of these studies for liturgical renewal, as is clearly stated in the above-mentioned message of the Synod of Bishops on Liturgical Issues:

The liturgical rite, in the broadest sense of the concept, is not something unchangeable. From the history of the Church it is known that church rites are developing. For this process, within the Church, a certain slowness, conservatism is inherent, but it cannot be interpreted as sacred unchangeability [...]. There is a special science - liturgy, which studies the historical development of the rite and allows us to distinguish between what is true, organic development, and what is only a dead imitation of reasons not related to the very ceremony. In the new circumstances of the freedom of our Church, experts in liturgical science grow up. We have great hope that due to their laborious work we will be able to better understand our special rite and many controversial liturgical problems in our nation will lose their severity.42

In the pastoral letter of the head of the UGCC, the His Holiness Svyatoslav (Shevchuk), entitled The Living Parish - a Place of Meeting with the Living Christ of December 2, 2011, which became the main document for UGCC development in the near future, attention is focused on the issue of liturgical

41 Постанови Синоду Єпископів Української Греко-Католицької Церкви, що відбувся у м. Аьвові (Брюховичі) 25-31 серпня 2005 року Божого, http://ugcc.ua/official/official-documents/ (10.02.2018).

42 Послання Синоду Єпископів Києво-Галицького Верховного Архиєпископства про хітургійні питання, https://risu.org.ua/ua/index/resourses/church_doc/ugcc_doc/33932/ (11.10.2012). 
piety. Liturgical prayer should not be considered mainly through the prism of church law; it must become "the acceptance of a gift from our Lord, who seeks to meet us to fill us with His grace and love." 43 A living parish is a place where all its actions proceed from the liturgical prayer, are nourished by it, draw from it its strength and inspiration.

Particular attention should also be paid to the vision for the renewal of liturgical piety of the current head of the Patriarchal Liturgical Commission Bishop Venedykt (Aleksiychuk) which is set out in his report at the Synod of the Bishops of the UGCC in 2012. Among the main factors on which the success of the liturgical renewal of the parish life depends, according to Bishop Venedykt, is the role of the bishop as a guarantor of true liturgical piety. "The ministry of the bishop is expression of faith and of Christ, and therefore the bishop should first of all be the one who keeps the rubrics everywhere." 44 The success of liturgical renewal also depends on the proper liturgical education of the priests and the liturgical catechesis. ${ }^{45}$ One of the global problems is the complexity of the liturgical rites, which are described as "a complex combination of monastic and parish traditions of the Jerusalem and Constantinople Cathedrals, as well as the liturgical statutes of the monasteries of the Studite and Savva." ${ }^{46}$ Considering the prayer life of the priests and the faithful in the parishes, the Bishop, quoting one of the promoters of the liturgical renewal - Fr. Juan Mateos, appeals to distinguish between parish and monastic traditions. ${ }^{47}$ According to this the liturgist is given the task to "Instruct the Patriarchal Liturgical Commission [...] to work out the project of a cathedral typicon of the UGCC" 48 in one of the resolutions of the Synod of Bishops of the UGCC in 2017.

43 Пастирський лист Блаженнішого Святослава до духовенства, монашества і усіх вірних Української Греко-Католицької Церкви «Жива парафія - місце зустрічі з живим Христом», http://www.ugcc.org.ua/2089.o.html (11.10.2012).

44 Преосв. Венедикт (Алексійчук), Літургійне життя на парохії, “Квартальний обіжник патріаршої літургійної комісії" 2012, березень-травень, р. 14.

45 Sее Венедикт (Алексійчук), Аітургійне життя на парохї̈, p. 15-17.

46 Венедикт (Алексійчук), Літургійне життя на парохії, р. 17.

47 Венедикт (Алексійчук), Аітургійне життя на парохії, р. 18.

48 Постанови Синоду Єпископів Української Греко-Католицької Церкви (Львів-Брюховичі, 03-12 вересня 2017 року Божого), http://ugcc.ua/official/official-documents/ (10.02.2018). 


\section{Streszczenie}

\section{Odnowa studiów liturgicznych w Ukraińskim Kościele Greckokato-} lickim

Artykuł dotyczy współczesnych prób przywrócenia teologii liturgicznej na Ukraińskim Katolickim Uniwersytecie. Autor dokonuje krótkiego przeglądu dziejów nauk teologicznych w różnych okresach historycznych, a szczególnie zatrzymuje się na okresie po II wojnie światowej i na okresie postsowieckim. W szczególności zwraca uwagę na trzy takie próby, za jakie można uznać:

- liturgiczną działalność metropolity Andrieja Szeptyckiego;

- działalność Katolickiego Uniwersytetu św. Klemensa w Rzymie;

- odnowę nauk liturgicznych na Ukraińskim Katolickim Uniwersytecie. 